\title{
Modeling nasopharyngeal carcinoma in three dimensions (Review)
}

\author{
PRABU SIVA SANKAR ${ }^{1,2 *}$, MOHD FIRDAUS CHE MAT ${ }^{3 *}$, KALAIVANI MUNIANDY $^{4}$, \\ BENEDICT LIAN SHI XIANG ${ }^{1}$, PHANG SU LING ${ }^{1}$, SUSAN LING LING HOE ${ }^{3}$, \\ ALAN SOO-BENG $\mathrm{KHOO}^{3 * *}$ and NETHIA MOHANA-KUMARAN ${ }^{1 * *}$ \\ ${ }^{1}$ School of Biological Sciences, Universiti Sains Malaysia, 11800 Gelugor; ${ }^{2}$ Infectomics Cluster, \\ Advanced Medical and Dental Institute, Universiti Sains Malaysia, 13200 Kepala Batas; \\ ${ }^{3}$ Molecular Pathology Unit, Cancer Research Centre, Institute for Medical Research, Jalan Pahang, 50588 Kuala Lumpur; \\ ${ }^{4}$ Institute for Research in Molecular Medicine, Universiti Sains Malaysia, 11800 Gelugor, Malaysia
}

Received December 5, 2015; Accepted August 19, 2016

DOI: $10.3892 / 01.2017 .5697$

\begin{abstract}
Nasopharyngeal carcinoma (NPC) is a type of cancer endemic in Asia, including Malaysia, Southern China, Hong Kong and Taiwan. Treatment resistance, particularly in recurring cases, remains a challenge. Thus, studies to develop novel therapeutic agents are important. Potential therapeutic compounds may be effectively examined using two-dimensional (2D) cell culture models, three-dimensional (3D) spheroid models or in vivo animal models. The majority of drug assessments for cancers, including for NPC, are currently performed with $2 \mathrm{D}$ cell culture models. This model offers economical and high-throughput screening advantages. However, 2D cell culture models cannot recapitulate the architecture and the microenvironment of a tumor. In vivo models may recapitulate certain architectural and microenvironmental conditions of a tumor, however, these are not feasible for the screening of large numbers of compounds. By contrast, 3D spheroid models may be able to recapitulate a physiological microenvironment not observed in 2D cell culture models, in addition to avoiding the impediments of in vivo animal models. Thus, the 3D spheroid model offers a more representative model for the study of NPC growth, invasion and drug response, which may be cost-effective without forgoing quality.
\end{abstract}

Correspondence to: Dr Nethia Mohana-Kumaran, School of Biological Sciences, Universiti Sains Malaysia, 11800 Gelugor, Penang, Malaysia

E-mail: nethiakumaran@usm.my

Dr Alan Soo-Beng Khoo, Molecular Pathology Unit, Cancer Research Centre, Institute for Medical Research, Jalan Pahang, 50588 Kuala Lumpur, Malaysia

E-mail: alankhoo@imr.gov.my

*, *** Contributed equally

Key words: nasopharyngeal carcinoma, 3-dimensional spheroid model, spheroids, 2-dimensional cell culture model, in vivo models

\section{Contents}

1. Introduction

2. 2D cell culture models

3. In vivo animal models

4. 3D spheroid models

5. 3D spheroid models for high-throughput drug screening

6. NPC 3D spheroids

7. Conclusion

\section{Introduction}

Nasopharyngeal carcinoma (NPC) is a type of cancer that affects the nasopharynx, commonly at the posterior and superior region in the fossa of Rosenmüller (1). It is a geographically distinct cancer, which is prevalent in south-east Asia, southern China and southern Africa (2). Viral, dietary, hereditary and lifestyle factors have been identified as risk factors for NPC (2). Current NPC treatment consists of radiotherapy, chemotherapy or chemo-radiotherapy; treatment resistance, particularly in advanced and recurrent cases of NPC, remains a challenge (2). NPC is staged according to the TNM system, whereby T describes the primary tumor invasion to the tissue or organs near the nasopharynx, $\mathrm{N}$ describes the spread to the lymph nodes and $\mathrm{M}$ indicates the metastasis of the tumor. NPC is usually detected at a late stage (III or IV) (2). Early-stage NPC has unspecific and ambiguous clinical symptoms such as neck lumps, bloodstained sputum, mild hearing loss and a unilateral headache which may be ignored by its sufferer or misdiagnosed by a doctor (3). Ultimately, this leads to a late disease presentation as well as detection. The pathogenesis of NPC involves genetic and epigenetic changes in the nasopharyngeal epithelium (4). Previous studies have improved current understanding of the potential molecular targets and signaling pathways involved in NPC pathogenesis, which has assisted the development of targeted therapies for the treatment of NPC, including cetuximab (Erbitux ${ }^{\circledR}$ ), bevacizumab $\left(\right.$ Avastin $\left.^{\circledR}\right)$, pazopanib $\left(\right.$ Votrient $\left.^{\circledR}\right)$, the phosphatidylinositol 3-kinase (PI3K)-mammalian target of rapamycin (mTOR) dual inhibitor PF-04691502 and apogossypolone (5-9). 
Potential therapeutic compounds are typically evaluated using two platforms: Two-dimensional (2D) cell culture models and in vivo animal models (10). However, the $2 \mathrm{D}$ model does not epitomize the microenvironment and architecture of a tumor in vivo, whereas experiments involving animal models are expensive, time-consuming and often include intricate surgeries. The 3D spheroid model may balance the cost-effectiveness of $2 \mathrm{D}$ models and the physiological complexity of animal models as the 3D model more closely recapitulates in vivo conditions of a tumor. The tumor phenotype, architecture and interaction with its microenvironment are crucial for determining the response and resistance of tumors to specific drug treatments $(11,12)$. In this review, the ethics, costs and practical considerations, including experimental procedures, are discussed, in addition to the biology of the models. This review will examine the advantages and briefly discuss the disadvantages that 3D spheroid models may provide for the study of NPC, as compared with 2D models and in vivo models.

\section{2D cell culture models}

The 2D cell culture model involves the culturing of cells in a plastic dish, which allows for the formation of a monolayer of cells adherent to the surface of the dish (13). 2D cultures are cost effective, simple to establish and easy to maintain (12). This ease of use facilitates the high-throughput screening of potential therapeutic agents.

The cells grown in this model have direct contact with the microenvironment and thus, maximum exposure to available nutrients and growth factors (14) (Fig. 1). The cells may adapt to the artificial growth conditions and upregulate certain growth-associated genes that promote cell proliferation (15). However, this model does not recapitulate the conditions of an in vivo tumor, which is composed of heterogeneous cell types with established concentration gradients and may have sub-maximal drug penetration $(13,16)$. Cells growing in a single monolayer format do not exhibit communication such as the cell-matrix crosstalk observed in three-dimensional microenvironment (Fig. 2), whereby the cells in three-dimensional cultures are in constant cross-talk with the stroma and other cells, including fibroblasts, immune cells and endothelial cells. The reactions of monolayer cultures to external stimuli often do not reflect a physiological effect, as demonstrated by trials investigating the administration of chemotherapeutic drugs, wherein drug sensitivity results obtained from monolayer cultures have been shown to be misleading and non-predictive for the in vivo trials because $2 \mathrm{D}$ cell culture models do not epitomize the tumor microenvironment and architecture that is present in vivo. These features of the $2 \mathrm{D}$ model impede the evaluation of drug penetration and drug resistance $(15,16)$.

In studies of NPC, 2D cell culture models are often utilized for various drug sensitivity assays (17-19). These usually demonstrate effective reactions in the micromolar or nanomolar ranges. Whether the results obtained from 2D cultures may be recapitulated in in vivo models requires further study, as the critical components of the in vivo tumor microenvironment are not present in the $2 \mathrm{D}$ model.

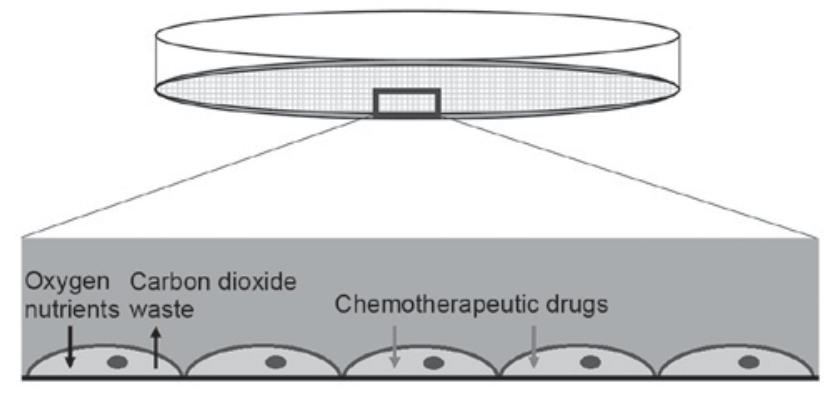

Figure 1. 2D cell culture model. Cells grown in 2D cell culture adhere to the plastic surface of the plate. They receive maximum exposure to drugs with optimal diffusion of nutrients and waste products. The $2 \mathrm{D}$ culture model provides the cells with the optimal conditions to proliferate, thus, inducing high proliferative rates, although this does not reflect the tumor behavior in vivo. 2D, two-dimensional.

\section{In vivo animal models}

Following identification of a potential therapeutic agent, it must be further examined in models that are more physiologically relevant to humans, usually an in vivo animal model and/or 3D cell culture model. The in vivo animal model may use mammals, including mice, rats, rabbits or monkeys; zebra fish or other animals are also viable models $(12,20)$. Mouse models utilized for drug testing often involve the use of tumor transplantations such as syngeneic models, subcutaneous xenografts or orthotopic xenograft of cell lines and patient-derived tumor xenograft (PDTX) models $(21,22)$. The syngeneic models are produced by allografting tumors from an animal into another animal that is genetically similar or of an identical strain. Subcutaneous xenografts involve the injection of cancer cells into the subcutaneous tissue of the mice, while orthotopic xenografts involve the injection of cancer cells according to the respective location of the cancer type. Both are artificial in comparison to genetically engineered mouse models, wherein the tumors may occur spontaneously at their natural site $(23,24)$. PDTX models are established by directly engrafting freshly isolated tumors from patients into immunodeficient mice $(22,25)$.

The xenograft model allows human cancer cells to directly interact with the murine stroma, including lymphatic and blood vessels, and therefore facilitates investigation of the growth behavior and drug responses of human cancer cells in vivo (12). Furthermore, as standardized techniques are used (the same number, passage and culture conditions of injected cells), this model provides improved control over the timing of tumor growth and the time points of drug administration, which enable the collection of reproducible data (12).

In addition to xenograft models for NPC $(26,27)$, an orthotopic model for NPC was also developed by luciferase-tagging of C666-1 and HONE-1 NPC cells and injecting them into the nasopharyngeal epithelium of immunodeficient NOD. $\mathrm{Cg}-P r k d c^{\mathrm{scid}} I l 2 r g^{\mathrm{tm} 1 \mathrm{Wjl}} / \mathrm{SzJ}$ mice (28). It was identified that, in a more natural microenvironment, the tumor cells exhibited characteristics that more accurately mimicked the metastatic and invasive human NPC, particularly during metastasis to numerous distant sites (bone, lung, liver). Therefore, this model may have advantages as a tool for the investigation of potential therapeutic agents for advanced NPC (28). Treatment with an 


\section{Spheroid Cross Section}
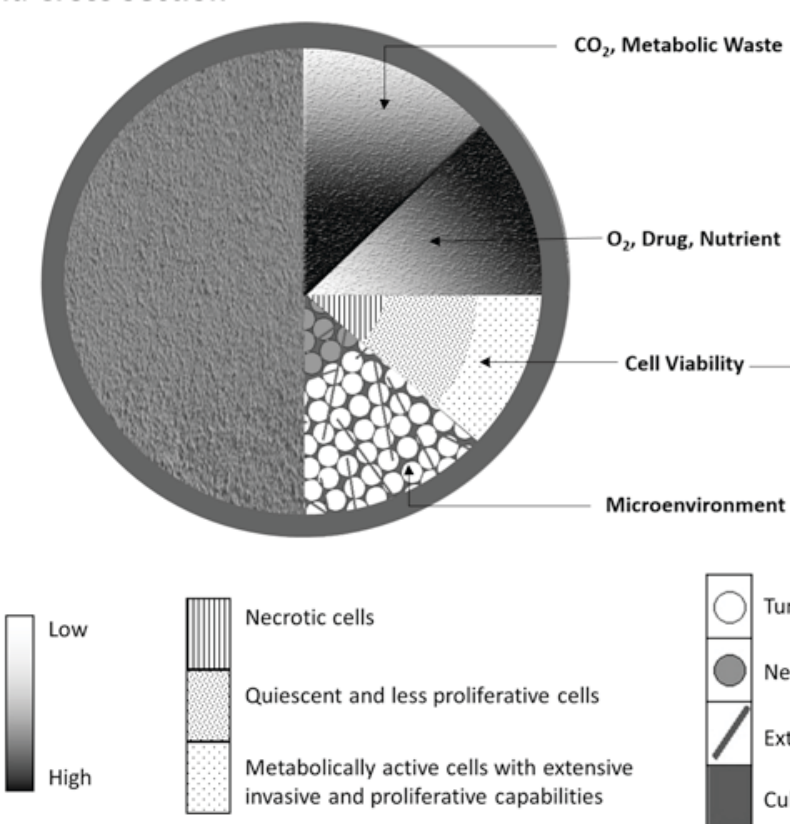

Necrotic cells

Quiescent and less proliferative cells

Metabolically active cells with extensive invasive and proliferative capabilities

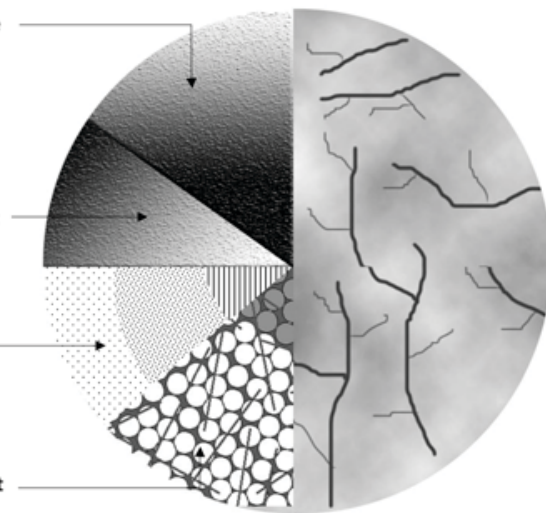

Tumor Cross Section

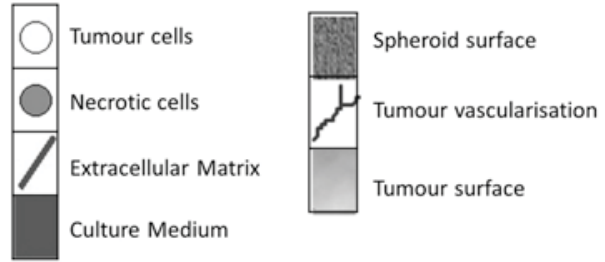

Figure 2. Similarities between the 3D spheroid model and a tumor in vivo. The spheroid received nutrients from the medium and the tumor through its vascularization, although they are subject to concentration gradients, which limit efficient diffusion. This creates a microenvironment, leading to various conditions of cells within the tumors and spheroids. The necrotic core exists due to the lack of available nutrients and the accumulation of waste, whereas the increased metabolic activity at the periphery is due to the more efficient diffusion of nutrients and waste. In each condition, the cells exist in a $3 \mathrm{D}$ conformation with interactions with the extracellular matrix. 3D, three-dimensional.

mTOR inhibitor and serolimus was observed to significantly inhibit the growth and metastasis of NPC tumors, suggesting that the $\mathrm{PI} 3 \mathrm{~K} /$ protein kinase $\mathrm{B}(\mathrm{AKT}) / \mathrm{mTOR}$ signaling pathway is a potential therapeutic target for the treatment of NPC (28).

Xenograft models offer a variety of benefits in drug sensitivity studies; however, they have their own disadvantages. The stromal component is of murine origin and, thus, reflects the microenvironment of mice and not humans (29). Furthermore, drug study data from xenograft models are not always similar to the data obtained in clinical trials $(29,30)$. Cell lines used to establish xenografts (with the exception of PDTXs) are subjected to strong selection for defective apoptosis, are not cultured in their natural environment and are implanted into a host that does not have an intact immune system (12). Orthotopic xenograft models require intricate surgery to implant the tumor cells at specific sites, including the brain, liver, kidney and nasopharynx, or they may not be representative of the in vivo behavior of tumor cells in metastasis and invasion, which is fundamental for therapeutic studies (28). These experiments are time consuming (30) and are subject to the regulations of animal ethics (12).

\section{3D spheroid models}

The 3D spheroid model was first created in 1970 (31) to study the mechanisms underlying tumorigenesis, including cell proliferation, invasion and metastasis (32). This model is based upon the physiological manner of culturing cells in their natural 3D state, where the cells aggregate to form multicellular or sphere-like structures, aided by artificial extracellular matrix (ECM) (11). 3D spheroids maintain their structural integrity, which is a key component for mimicking the conditions of a tumor in vivo, in addition to the presence of the ECM $(33,34)$. Ideally, the 3D spheroid model serves to provide a balance between $2 \mathrm{D}$ culture and in vivo animal approaches. 3D spheroids may be used as simple cancer cell line spheroids, co-cultures of cancer cells with other cell types (e.g. fibroblasts) within the spheroid (35) or as a culture for the maintenance of patient tissues (36).

A key characteristic of the 3D spheroid is that it recapitulates the in vivo tumor microenvironment and architecture (37) (Fig. 2). Three-dimensional spheroids grow suspended in a liquid medium, which supplies nutrients and facilitates gas exchange and waste disposal (38). Due to its structure, a gradient of nutrients and oxygen forms as cells go deeper into the tumors. Peripheral cells which are closer to the vasculature have maximal exposure to nutrients, oxygen and chemotherapeutic agents. Due to poor vascularization within solid tumors, concentration gradients of oxygen, nutrients and metabolic wastes are established (39). The shortage of oxygen and nutrients also creates hypoxic regions in the center of the tumor and cells in these regions often exhibit drug resistance (40), as drugs are often aimed to target rapidly growing cells and some are inefficient in the acidic microenvironments (39).

The 3D spheroid model may also be utilized to investigate drug bioavailability in addition to sensitivity. Melanoma spheroids treated with the B-cell lymphoma 2 homology domain 3-mimetic ABT-737 after seven days of growth demonstrated that spheroid peripheral cells were responsive to the drug 
Table I. Comparison of the techniques of spheroid culture, associated with cell type, cell density, method of culture, type of base layer and the medium cocktail.

\begin{tabular}{|c|c|c|c|c|c|}
\hline Cells & Cell density & Method & Base layer & Medium cocktail & References \\
\hline HONE-1 & $3 \times 10^{3} / \mathrm{NA}$ & Liquid overlay method & Matrigel & RPMI + 2\% Matrigel & (8) \\
\hline C666-1 & $5 \times 10^{3} / 96$ well & Hanging drop & No & $\begin{array}{l}\text { DMEM/F12 serum } \\
\text { free media }+20 \mathrm{ng} / \mathrm{ml} \\
\text { EGF, } 20 \mathrm{ng} / \mathrm{ml} \mathrm{FGF} \mathrm{and} \\
20 \mathrm{ng} / \mathrm{ml} \mathrm{IGF}\end{array}$ & $(42)$ \\
\hline HONE-1 & $1.3 \times 10^{4} / \mathrm{NA}$ & Drug screening method & No & IMDM with $10 \%$ serum & (43) \\
\hline HK1 & $1.7 \times 10^{5} / \mathrm{NA}$ & & & & \\
\hline TW01 & $\begin{array}{l}5 \times 104 / 10 \mathrm{~cm} \\
\text { plate }\end{array}$ & $\begin{array}{l}\text { Ultra Low attachment } \\
\text { plates }\end{array}$ & No & DMEM with $4 \%$ serum & (67) \\
\hline HONE-1 & $1 \times 10^{4} / 48$ well & Liquid overlay method & Matrigel & RPMI + 2\% Matrigel & (73) \\
\hline C666-1 & $2 \times 10^{3} / 24$ well & $\begin{array}{l}\text { Ultra Low attachment } \\
\text { plates }\end{array}$ & No & $\begin{array}{l}\mathrm{DMEM} / \mathrm{F} 12 \text { serum free } \\
\text { media }+20 \mathrm{ng} / \mathrm{ml} \text { EGF, } \\
20 \mathrm{ng} / \mathrm{ml} \mathrm{bFGF} \text { and } \\
20 \mathrm{ng} / \mathrm{ml} \mathrm{insulin}\end{array}$ & (74) \\
\hline C666-1, CNE2 & $1 \times 10^{6} / \mathrm{T} 25$ & $\begin{array}{l}\text { Ultra-Low attachment } \\
\text { plates }\end{array}$ & No & $\begin{array}{l}\mathrm{DMEM} / \mathrm{F} 12 \text { serum free } \\
\text { media }+20 \mathrm{ng} / \mathrm{ml} \mathrm{EGF}+ \\
20 \mathrm{ng} / \mathrm{ml} \mathrm{bFGF}+2 \% \mathrm{~B} 27 \text { and } \\
1 \% \text { penicilin-streptomycin }\end{array}$ & $(75)$ \\
\hline C666-1 & $2 \times 10^{3} / 24$ well & $\begin{array}{l}\text { Ultra-Low attachment } \\
\text { plates }\end{array}$ & No & $\begin{array}{l}\text { DMEM/F12 serum free } \\
\text { media }+20 \mathrm{ng} / \mathrm{ml} \text { EGF, } \\
20 \mathrm{ng} / \mathrm{ml} \mathrm{bFGF} \text { and } \\
20 \mathrm{ng} / \mathrm{ml} \mathrm{IGF}\end{array}$ & (76) \\
\hline SUNE-1, CNE2 & $1 \times 10^{4} / 24$ well & Liquid overlay method & Matrigel & RPMI with 5\% serum & (77) \\
\hline CNE2 & NA & Liquid overlay method & Agar & RPMI & (78) \\
\hline Xeno-C15 & $1 \times 10^{5} / 96$ well & $\begin{array}{l}\text { Ultra-Low attachment } \\
\text { plates }\end{array}$ & No & RPMI with 5\% serum & (79) \\
\hline Xeno-C15 & NA & $\begin{array}{l}\text { Ultra-Low attachment } \\
\text { plates }\end{array}$ & No & RPMI with $7.5 \%$ serum & (80) \\
\hline C666-1 & $1 \times 10^{6} / 24$ well & $\begin{array}{l}\text { Ultra-Low attachment } \\
\text { plate }\end{array}$ & No & $\begin{array}{l}\text { DMEM/F12 serum free } \\
\text { media }\end{array}$ & $(81)$ \\
\hline TW03 & $1 \times 10^{2} / \mathrm{NA}$ & Liquid overlay method & Agar & IMDM with $1 \%$ serum & $(82)$ \\
\hline CNE2 & NA & Liquid overlay method & Agar & NA & (83) \\
\hline HONE-1 & $4 \times 10^{3} / \mathrm{NA}$ & Liquid overlay method & Matrigel & DMEM with $10 \%$ serum & $(85)$ \\
\hline C666-1 & $1 \times 10^{3} / 24$ well & $\begin{array}{l}\text { Ultra-Low attachment } \\
\text { plates }\end{array}$ & No & $\begin{array}{l}\text { DMEM/F12 serum free } \\
\text { media }\end{array}$ & (86) \\
\hline NP69 & $5 \times 10^{4} / \mathrm{NA}$ & Liquid overlay method & Collagen & $\begin{array}{l}\text { MCDB151 low calcium } \\
(0.1 \mathrm{mM}) \text { media with } \\
1 \% \text { serum + other } \\
\text { growth supplements }\end{array}$ & (87) \\
\hline CNE2 & NA & Liquid overlay method & Agar & NA & (88) \\
\hline C666-1 & $1 \times 10^{3} / 24$ well & $\begin{array}{l}\text { Ultra-Low attachment } \\
\text { plates }\end{array}$ & No & $\begin{array}{l}\mathrm{DMEM} / \mathrm{F} 12 \text { serum free } \\
\text { media }+20 \mathrm{ng} / \mathrm{ml} \\
\mathrm{EGF}+10 \mathrm{ng} / \mathrm{ml} \mathrm{bFGF}+ \\
0.4 \% \mathrm{BSA} \text { and } 2 \% \mathrm{~B} 27\end{array}$ & (89) \\
\hline HONE-1 & $\begin{array}{c}0.5 \times 10^{2}- \\
1.5 \times 10^{2} / \mathrm{T} 25\end{array}$ & Liquid overlay method & Gelatin & DMEM with $10 \%$ serum & (90) \\
\hline TW01 & $1 \times 10^{3} / 96$ well & Liquid overlay method & Agar & DMEM with $10 \%$ serum & (91) \\
\hline CNE2 & $2 \times 10^{2} / \mathrm{NA}$ & Liquid overlay method & Matrigel & RPMI with $10 \%$ serum & $(92)$ \\
\hline TW01, TW06 & $2 \times 10^{4} / 6$ well & Liquid overlay method & $\begin{array}{l}\text { Agar } \\
(0.3 \%)\end{array}$ & DMEM with $10 \%$ serum & (93) \\
\hline CNE2 & $2 \times 10^{4} / \mathrm{NA}$ & $\begin{array}{l}\text { Ultra-low attachment } \\
\text { plates }\end{array}$ & No & $\begin{array}{l}\mathrm{DMEM} / \mathrm{F} 12 \text { serum free } \\
\text { media }+10 \mathrm{ng} / \mathrm{ml} \text { EGF, } \\
10 \mathrm{ng} / \mathrm{ml} \mathrm{FGF} \mathrm{and} \mathrm{B27}\end{array}$ & (94) \\
\hline
\end{tabular}


Table I. Continued.

\begin{tabular}{|c|c|c|c|c|c|}
\hline Cells & Cell density & Method & Base layer & Medium cocktail & References \\
\hline C666-1 & $1 \times 10^{5} / 24$ well & Ultra-low attachment & No & RPMI with $10 \%$ serum & (95) \\
\hline HONE-1 & $4 \times 10^{4} / 24$ well & plates & & & \\
\hline HK1 & $4 \times 10^{4} / 24$ well & & & & \\
\hline $\begin{array}{l}\text { CNE1, } \\
\text { CNE2 }\end{array}$ & $1 \times 10^{3} / 6$ well & $\begin{array}{l}\text { Ultra-Low attachment } \\
\text { plates }\end{array}$ & No & $\begin{array}{l}\text { DMEM/F12 serum free } \\
\text { media }+20 \mathrm{ng} / \mathrm{ml} \text { PDGF } \\
+100 \mathrm{ng} / \mathrm{ml} \mathrm{EFG}+1 \% \mathrm{~N} 2, \\
2 \% \mathrm{~B} 27 \text { and } 1 \% \text { antimycotic }\end{array}$ & (96) \\
\hline $\begin{array}{l}\text { TW02, } \\
\text { TW04 }\end{array}$ & $5 \times 10^{2} / 24$ well & Liquid overlay method & Agar & $\begin{array}{l}\text { DMEM serum free media + } \\
20 \mathrm{ng} / \mathrm{ml} \mathrm{EGF} \text { and } \\
20 \mathrm{ng} / \mathrm{ml} \mathrm{bFGF}\end{array}$ & (97) \\
\hline CNE2 & NA & Liquid overlay method & Agar & NA & (84) \\
\hline CNE2 & NA & Liquid overlay method & Agar & NA & (98) \\
\hline HK1 & $5 \times 10^{3} / 96$ well & Liquid overlay method & $\begin{array}{l}\text { Agar } \\
(1.5 \%)\end{array}$ & RPMI with $10 \%$ serum & $\begin{array}{l}\text { Lian et al., } \\
\text { (unpublished) }\end{array}$ \\
\hline C666-1 & $1 \times 10^{4} / 96$ well & Liquid overlay method & Agar & $\begin{array}{l}\text { DMEM/F12 serum } \\
\text { free media }+10 \mathrm{ng} / \mathrm{ml} \\
\text { EGF and } 10 \mathrm{ng} / \mathrm{ml} \mathrm{bFGF}\end{array}$ & (unpublished) \\
\hline
\end{tabular}

NA, information not available; IMDM, Iscove's modified Dulbecco's medium; DMEM, Dulbecco's modified Eagle's medium; F12, Ham's F-12 nutrient mixture; MCDB151, molecular, cellular, and developmental biology 151 medium; B27, B-27 ${ }^{\circledR}$ supplement serum-free; EGF, epidermal growth factor; bFGF, basic fibroblast growth factor; BSA, bovine serum albumin; IGF, insulin-like growth factor; FGF, fibroblast growth factor.

and that core cells were not, indicating that the drug did not diffuse effectively into large tumors (41). This observation was concordant with another study, which used a CXCL8 peptide inhibitor, termed Ac-RRWWCR-NH2, the C-X-C motif chemokine receptor 2 specific inhibitor SB225002 and the PI3K/AKT inhibitor LY294002 to target chemokines in NPC C666-1 spheroids (42). HONE-1 spheroids, which were used to investigate the effects of lapatinib, a dual tyrosine kinase inhibitor against epithelial growth factor receptor and human epidermal growth factor receptor 2, also exhibited similar drug diffusion problems (43).

The ECM is another feature that affects the biomimetic capacity of the 3D spheroid model. Under in vivo conditions, tumor cells establish biological crosstalk with the ECM (44). This interaction with the ECM may determine the level of cancer cell activity, including aggressiveness (45). Cells secrete various components, or induce other cells to secrete soluble factors, in a paracrine manner, including matrix metalloproteinases (MMPs), which allow cancer cells to penetrate the matrix, invade and metastasize (46-48). The ECM components secreted by spheroids include fibronectin, collagen, laminin and glycosaminoglycan (49-51). Each of these proteins has specific effects on the progression of cancer; laminin, for example, has a role in cancer invasion and metastasis (52).

Following their formation, 3D spheroids must be embedded in a matrix to enable them to proliferate and invade as tumors in vivo. The matrix consists of a scaffold, a buffering system, and nutrients, prepared using components that recapitulate the in vivo physiology. Typical components used include Eagle's minimal essential medium, L-glutamine, fetal bovine serum, sodium bicarbonate and Cultrex ${ }^{\circledR}$ Bovine Collagen I (Trevigen Inc., Gaithersburg, MD, USA) $(53,54)$. Collagen type I is a major ECM protein of human organs and is available in abundance as a reagent with Cultrex ${ }^{\circledR}$ Bovine Collagen I (55). This component of the 3D spheroid ECM provides a cell scaffold, a structure for nutrient delivery and a matrix for cell signaling whilst having the advantage of being easily manipulated for the required tensional force and elastic modulus (53). The components used are variable and are available commercially (Matrigel and hydrogels), and these have been reviewed extensively in previous studies (14,56-58). The components used to prepare the polymers, the polymer concentration and the polymerization conditions affect the interactions and phenotype of the spheroid; therefore, consistency in the method of polymer preparation is crucial (59). Matrix stiffness has been previously demonstrated to affect cell invasion, in addition to the expression of MMPs $(60,61)$.

The 3D spheroid model offers a more ethical approach to the screening of therapeutic agents as no animal sacrifice or surgery is required. The model also allows freedom to use reagents that recapitulate components that closely mimic humans, such as the collagen type I rather than the murine system. This may confer an advantage as the 3D model is intended to approximate the microenvironment of human tumors. Furthermore, the cells may be observed and quantified with imaging equipment, staining dyes and software in real time $(41,62)$. Utilizing the 3D spheroid model is also cost-effective and efficient, as high-throughput drug sensitivity screening may be conducted, as compared with animal studies in which they cannot (12). Therefore, the 3D model 


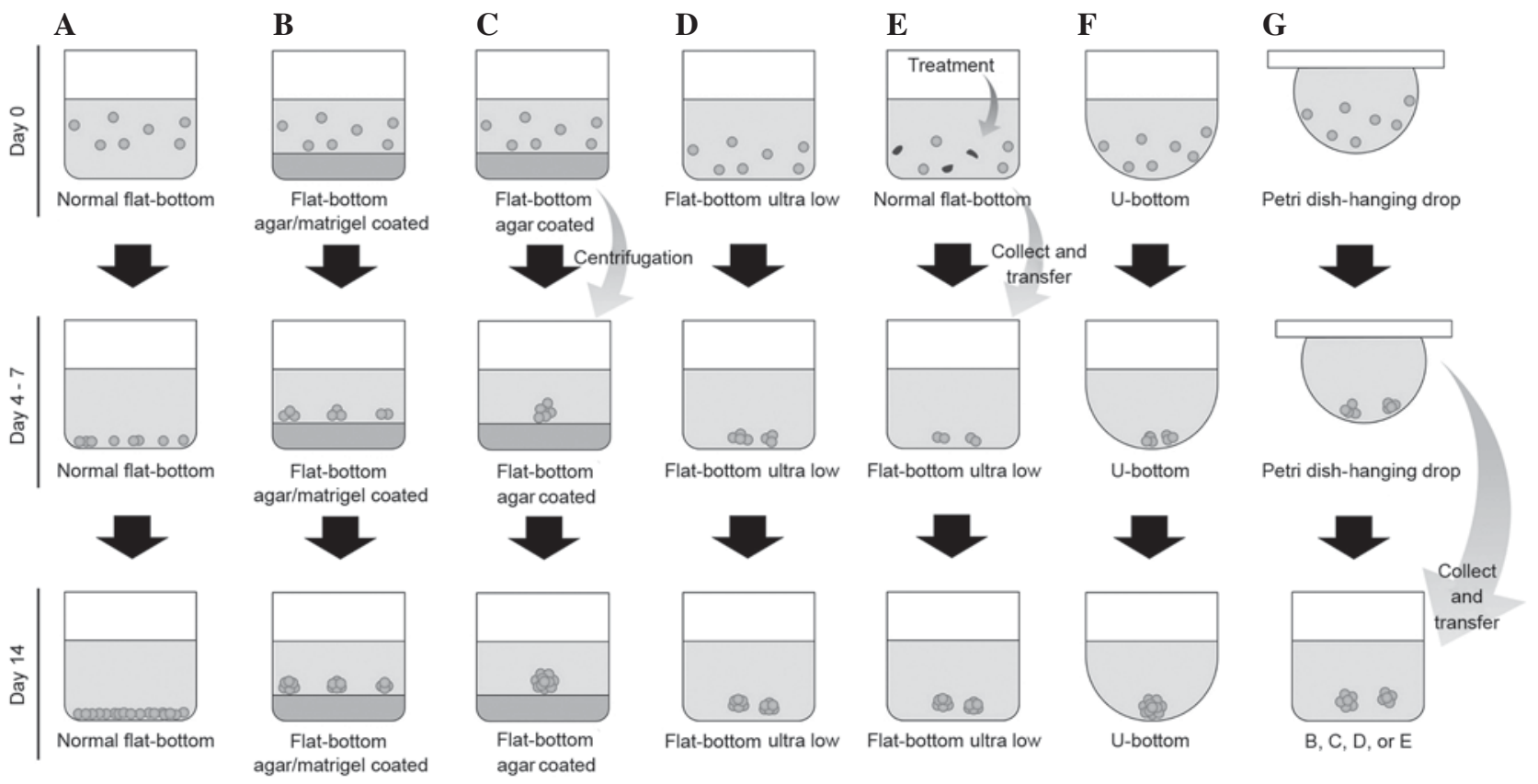

Figure 3. Comparison between various methods and plate types used for the generation of 3D spheroids. (A) Normal flat-bottom cell culture plate; (B) Normal flat-bottom cell culture plate coated with agarose or Matrigel; (C) Normal flat-bottom cell culture plate coated with agarose; the cells clump due to centrifugation; (D) Ultra-Low attachment plate; (E) Modification of drug resistant spheroid: drug treatment is conducted in a ultra-low attachment plate prior to spheroid culture; (F) U-bottom plate; (G) Hanging drop method using a petri dish: following the formation of cell clumps, the aggregates may be transferred into plate B, C, D or E. 3D, three-dimensional.
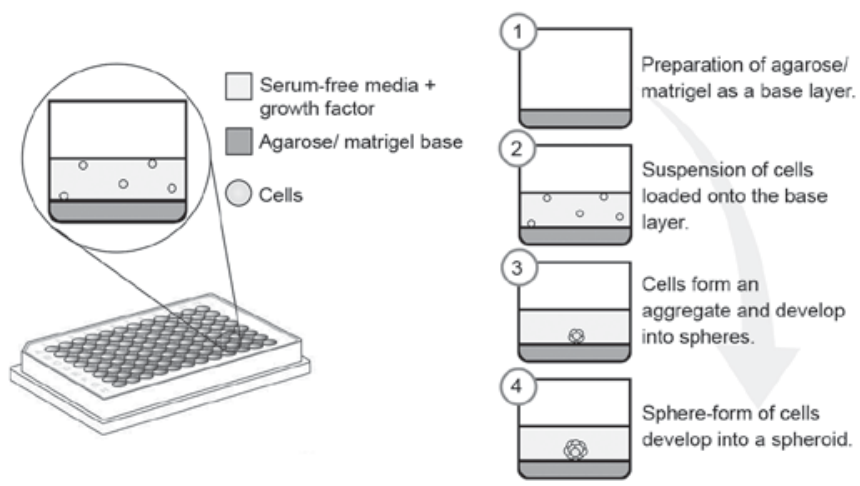

Figure 4. Formation of spheroids using either agarose or Matrigel as the base layer. Various concentrations of agarose or Matrigel may be applied as the base layer. The cells are suspended in serum-free medium with addition of growth factors such as basic fibroblast growth factor and epidermal growth factor. After four days, cells aggregate and form spheroids.

allows the antitumor effects of small molecule inhibitors and other chemotherapeutic agents, to be determined economically in a physiological environment. This may accelerate the drug screening process from laboratory to clinical trials. A preliminary study of a cancer tissue-originated spheroid (CTOS) demonstrated the use of 3D spheroid culture to form spheroids from human colorectal cancer, non-small cell lung cancer and urothelial tumors (63). CTOS retained the characteristics of the original tumors, a feature that may be utilized not only for drug screening, but also for future personalized therapy (64).

The terms 'sphere', 'sphere-forming' and 'spheroid' are also used in stem cell (SC) and cancer SC (CSC) research to refer to non-adherent cell growth in a serum-free medium which is typically supplemented with growth factors (65). The 3D spheroids are typically formed by the cells coming together to a compact ball or cluster of cells due to gravitational pull with a focus point formed by the meniscus of the agarose, as well as other factors depending on the type of method used to form the spheroid. The spheres in SC and CSC are also the same in the sense that their final appearance is essentially the same as a spheroid. However, the two principal differences between 3D spheroids and SC/CSC spheroids are the initial cell seeding number and the purpose of each assay. Three-dimensional spheroid culture generally uses at least 5,000 cells/well in a 6-well plate as an initial seeding number to begin non-adherent cell growth, whereas SC/CSC spheroid assays use ideally one cell/well in a 96-well plate as a seeding number to accurately assess self-renewal ability of putative SC or CSCs (66). In consideration of the difficulty of successful growth from a single cell for spheroid culture in SC/CSC research, a low clonal density of $\leq 20$ cells $/ \mu$ l is considered appropriate for clonal growth in order to prevent cell aggregation or sphere fusion (66).

Similar to other tumor models, the 3D spheroid model offers divergent advantages and disadvantages. One of the disadvantages of the 3D spheroid model is the lack of tumor complexity, which can be overcome by the increase in the range and convolution of models applicable to researchers including co-culture system and patient-derived spheroids $(67,68)$. Although we have the capability to recreate the tumor microenvironment architecture with a matrix of the 3D cell culture, variability in the matrix, particularly ones that are biologically derived, may yield non-reproducible results. However, the use of synthetic matrixes supplemented with growth factors may avert this issue (69). 
A
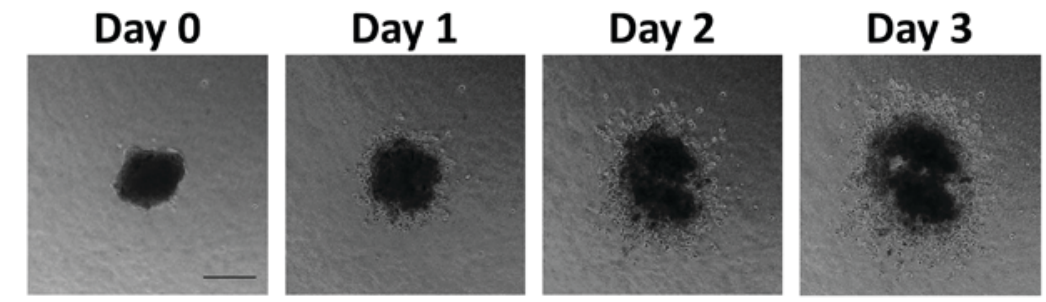

B

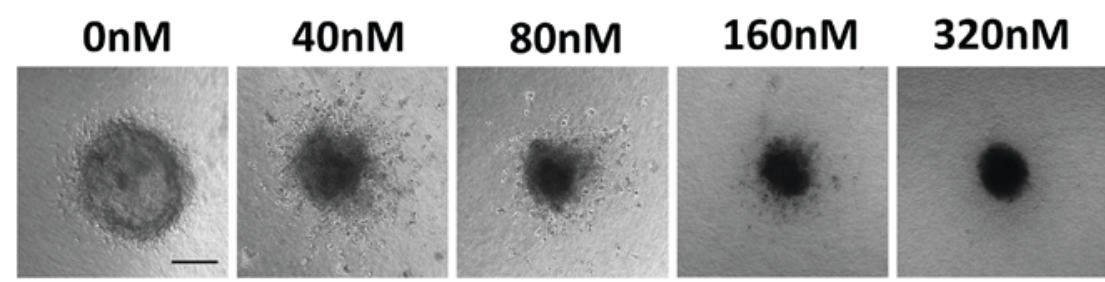

Figure 5. Growth and invasion of the HK1 spheroids into the collagen matrix over three days. (A) Phase contrast images of spheroid growth and invasion were taken every $24 \mathrm{~h}$ using the Nikon $\mathrm{T}_{i}$ Eclipse inverted fluorescence microscope; scale bar, $200 \mu \mathrm{m}$ (B) Spheroids were treated with the chemotherapeutic drug Flavopiridol at the concentrations indicated. Phase contrast images taken every $24 \mathrm{~h}$ reveal that Flavopiridol induced a dose-dependent inhibition of spheroid growth and invasion (slope represents level of growth and invasion of the spheroids); scale bar, $200 \mu \mathrm{m}$.

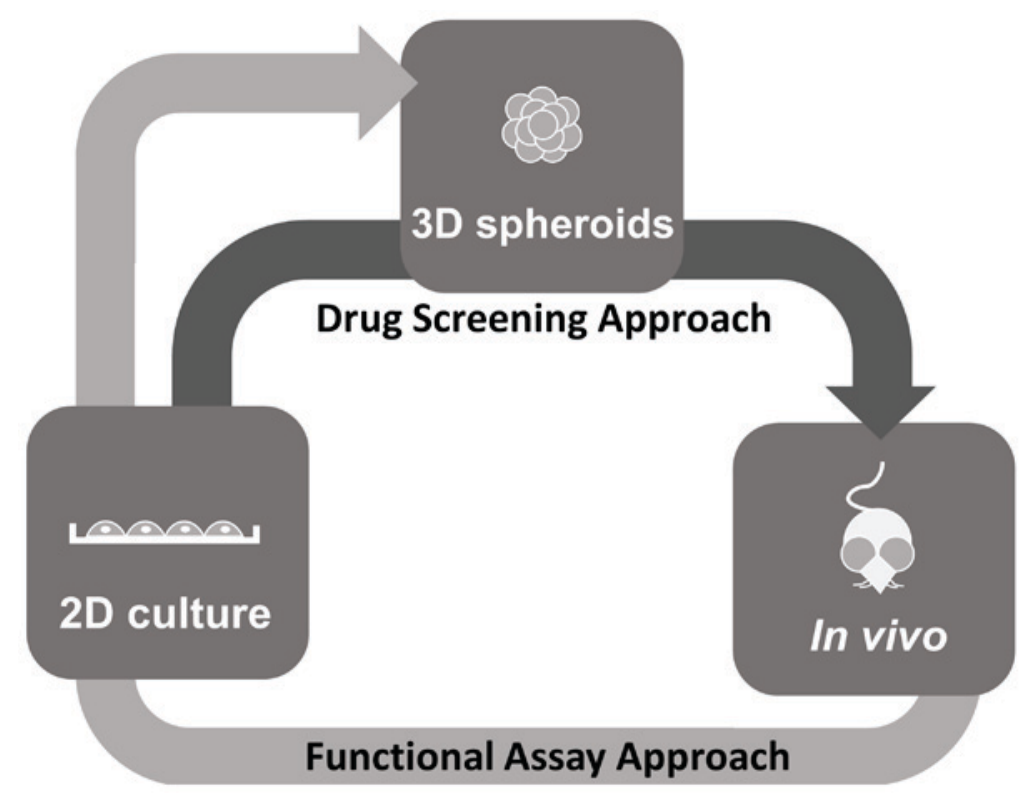

Figure 6. Proposed application of 3D spheroid models for therapeutic studies. Drug Screening Approach (dark grey arrow): The traditional 2D model is more economical and suitable for high-throughput screening compared with the 3D model. However, 2D models do not represent human cancer as in vivo models do. The transition from the 2D to the 3D model may allow for a relatively high throughput screening with the advantage of a more physiological model. The 3D model mimics the complex in vivo microenvironment, particularly with regard to gene expression, signaling pathways and drug sensitivity. The transition from the 3D model to animal models may also reduce the number of animals used for drug testing and may be more economical as animal models are costly and time-consuming. By using 3D models, more detailed data regarding drug suitability may be obtained prior to initiating in vivo studies with animal models. Functional Assay Approach (light grey arrow): In vivo tumor models may also be developed as in vitro 3D spheroid models for high-throughput functional assays. Cell lines can first be established and characterized in 2D from tumors obtained from the in vivo models such as the genetically engineered mouse models and xenografts and transitioned into 3D spheroids for functional studies. 2D, two-dimensional; 3D, three-dimensional.

\subsection{D spheroid models for high-throughput drug screening}

Inefficient drug delivery is one of the contributing factors to the mechanisms underlying drug resistance in human cancers (70). Despite possessing capacity for high-throughput drug screening, the 2D cell culture model cannot recapitulate the in vivo cellular architecture and microenvironment (71). In contrast, the 3D spheroid model used for high-throughput drug screening is able to more accurately predict in vivo drug efficacy and enhances the understanding, design and development of improved drug delivery systems (72). Compared with in vivo tumor growth, the size and uniformity of 3D spheroids are more consistent and adjustable, thus, making the model relatively more suitable for conducting drug screening (72). The 
standardization of spheroid morphology, with regard to the uniformity of size and number, may be determined by the cell seeding density (72).

In order to improve drug screening using a 3D spheroid model, a previous study grew cells as multicellular spheroids rather than from spheroids from single-cell clones, as physiological human tumors are composed of multiple cell types, including epithelial cells, fibroblasts, mesenchymal stem cells, endothelial cells and immune cells comprising T, B and natural killer cells (37). The drug penetration into these multicellular spheroid aggregates enables investigation into the modulation of drug diffusion, sensitivity and resistance in cancers (37).

\section{NPC 3D spheroids}

A number of previous studies have developed improved NPC models based on spheroid cultures; these have increased in number due to novel culture methods emerging from the field of tissue engineering (Table I) $(8,42,43,67,73-98)$. Formerly, the utilization of ultra-low attachment plates and hanging drop were the most common methods used to generate spheroids from NPC cells (74). Previous studies have used a liquid overlay culture method with improved medium cocktails to grow spheroids for NPC research $(73,75)$. Several methods of 3D spheroid generation are presented and compared in Fig. 3.

As described, spheroids are established by the aggregation of cells creating a sphere-like structure, which interacts with the artificial ECM (12). The artificial ECM varies in composition depending on the method of spheroid culture. Some studies have utilized Matrigel, which served as a base for spheroid formation in the liquid overlay method $(8,73,77,85,92)$. By contrast, the use of agarose-coated plates is more common in the liquid overlay method, with agarose being more economical compared with Matrigel (56). Furthermore, cell density and the cell medium cocktail also varies between studies (Table I). The processes of generating spheroids using agarose or Matrigel as the base layer are depicted in Fig. 4.

A number of previous studies have utilized spheroids generated from the C666-1 Epstein-Barr virus (EBV)-positive NPC cell line to study the effects of therapeutic agents (76-78). However, some studies have also used various EBV-negative NPC cell lines, including CNE1, CNE2, HONE-1, HONE-2, TW01, TW02, TW03, TW04, TW06, HK1 and SUNE-1 (references are presented in Table I). The application of spheroids generated from NPC xenografts is limited and primarily focused on the use of $\mathrm{C} 15$, a xenograft derived from a North African NPC patient, for drug evaluations $(79,80)$. Spheroids generated from C666-1 cells were used to identify CSCs in EBV-positive NPC (81). C666-1 is a distinctive NPC cell line that preserves the native EBV genome (99), as EBV has been detected in nearly all non-keratinizing NPC cases (100). HK1 cells demonstrated the ability to form spheroids (Fig. 5). In addition, it was previously observed that HK1 contained a subset of cells termed side population (SP) cells, which were enriched with CSC-associated genes (101). A separate study identified certain CSC genes to be responsible for the formation of spheroids in HK1 (97). Together, this suggests an association between CSCs, SP cells and spheroids.

Other studies, which have utilized the spheroid model, previously identified that NPC CSCs also exhibited chemotherapy- and radiotherapy-resistance with self-renewal properties. Such NPC CSCs may potentially affect post-therapeutic cancer relapses $(102,103)$; these studies may assist the development of new therapies for NPC. The 3D spheroid model may facilitate the identification of potential drugs that inhibit CSCs. Chan et al (76) identified that ICG-001, a specific CREB-binding protein (CBP)/ $\beta$-catenin antagonist, blocked the $\mathrm{CBP} / \beta$-catenin-mediated transcription of CSC-associated genes and synergistically reduced the formation of NPC spheroids when administered with cisplatin. In addition, spheroids may also be utilized in various assays such as cell differentiation assays (58), invasion assays (60), immunofluorescence staining and fluorescence-activated cell sorting analysis (74).

The similarity of 3D spheroids to in vivo tumors has enabled the study of growth, invasion and drug sensitivity of NPC HK1 spheroids towards the chemotherapeutic agent Flavopiridol in which HK1 cell spheroids were generated using the liquid overlay method $(54,55)$. HK1 cells $(\sim 5,000)$ were seeded on hardened agar and incubated at $37^{\circ} \mathrm{C}$ for three days. Once formed, the spheroids were embedded into a collagen matrix and medium was added to the solidified collagen matrix. It was observed that the HK1 spheroids grew and invaded the collagen matrix over three days (Fig. 5A). In a separate experiment, spheroids were treated with Flavopiridol at increasing concentrations for a period of three days from the day the spheroid was embedded (day 0). The results suggested that Flavopiridol inhibited spheroid growth and invasion in a dose-dependent manner (Fig. 5B). These cell line-derived spheroids have previously been used for selective (low-throughput) drug testing in NPC. The development of 3D spheroids for high-throughput drug screening for NPC may improve the methods of screening novel therapeutic agents for the treatment of this type of cancer.

\section{Conclusion}

The 3D spheroid model, which mimics the tumor architecture and microenvironment, offers a valuable approach to the study of NPC tumor biology in addition to providing a scalable system, which could allow the increase in quantity to meet the requirements for high-throughput drug screening. The 3D model enhances the selection of effective drug candidates and will allow for the prioritization of testing for drug candidates that seem the most effective prior to in vivo studies (Fig. 6). Additionally, high-throughput functional assays using these $3 \mathrm{D}$ models to assess the hallmarks of cancer, including cell viability, proliferation, apoptosis, cell cycle, migration and invasion may enhance the value of these models for the development of novel NPC therapies.

\section{Acknowledgements}

The authors would like to thank the Director General of Health, Malaysia for the permission to publish this review and the Director of the Institute for Medical Research for the support provided. This work was funded by the Universiti Sains Malaysia, Research University Individual Grant (grant no. 1001/PBIOLOGI/812124) and the Fundamental Research Grant Scheme, Ministry of Education Malaysia (grant no. 203/PBIOLOGI/6711355), in addition to the Universiti 
Sains Malaysia Vice Chancellor's Award, the Universiti Sains Malaysia Fellowship, the MAKNA Cancer Research Award 2014 of the National Cancer Council and the MAKNA Cancer Research Award 2015 by National Cancer Council (grant no. 304/PBIOLOGI/650828/M121).

\section{References}

1. Loh LE, Chee TS and John AB: The anatomy of the Fossa of Rosenmuller-its possible influence on the detection of occult nasopharyngeal carcinoma. Singapore Med J 32: 154-155, 1991.

2. Pua KC, Khoo AS, Yap YY, Subramaniam SK, Ong CA, Gopala Krishnan G and Shahid H; Malaysian Nasopharyngeal Carcinoma Study Group: Nasopharyngeal Carcinoma Database. Med J Malaysia 63 (Suppl C): 59-62, 2008.

3. Khoo ASB and Pua KC: Nasopharyngeal Carcinoma: Keys for Translational Medicine and Biology. Busson P (ed). Landes Bioscience, Austin, TX, 2013.

4. Lo KW, Chung GT and To KF: Deciphering the molecular genetic basis of NPC through molecular, cytogenetic, and epigenetic approaches. Semin Cancer Biol 22: 79-86, 2012.

5. Chan AT, Hsu MM, Goh BC, Hui EP, Liu TW, Millward MJ, Hong RL, Whang-Peng J, Ma BB, To KF, et al: Multicenter, phase II study of cetuximab in combination with carboplatin in patients with recurrent or metastatic nasopharyngeal carcinoma. J Clin Oncol 23: 3568-3576, 2005.

6. Lee NY, Zhang Q, Pfister DG, Kim J, Garden AS, Mechalakos J, $\mathrm{Hu} \mathrm{K}$, Le QT, Colevas AD, Glisson BS, et al: Addition of bevacizumab to standard chemoradiation for locoregionally advanced nasopharyngeal carcinoma (RTOG 0615): A phase 2 multi-institutional trial. Lancet Oncol 13: 172-180, 2012

7. Lim WT, Thng C, Toh CK, et al: A phase II study of GW786034 (pazopanib) in Asian patients with recurrent/metastatic undifferentiated nasopharyngeal carcinoma. J Clin Oncol 28 : abstract 5556, 2010.

8. Wong $\mathrm{CH}$, Loong HH, Hui CW, Lau CP, Hui EP, Ma BB and Chan AT: Preclinical evaluation of the PI3K-mTOR dual inhibitor PF-04691502 as a novel therapeutic drug in nasopharyngeal carcinoma. Invest New Drugs 31: 1399-1408, 2013.

9. He JH, Liao XL, Wang W, Li DD, Chen WD, Deng R, Yang D, Han ZP, Jiang JW and Zhu XF: Apogossypolone, a small-molecule inhibitor of Bcl-2, induces radiosensitization of nasopharyngeal carcinoma cells by stimulating autophagy. Int J Oncol 45: 1099-1108, 2014.

10. Nyga A, Cheema U and Loizidou M: 3D tumour models: Novel in vitro approaches to cancer studies. J Cell Commun Signal 5: 239-248, 2011.

11. Bissell MJ and Radisky D: Putting tumours in context. Nature Rev Cancer 1: 46-54, 2001

12. Baeaumont KA, Mohana-Kumaran N and Haass NK: Modeling melanoma in vitro and in vivo. Healthcare (Basel) 2: 27-46, 2014.

13. Edmondson R, Broglie JJ, Adcock AF and Yang L: Three-dimensional cell culture systems and their applications in drug discovery and cell-based biosensors. Assay and Drug Development Technologies 12: 207-218, 2014.

14. Huang H, Ding Y, Sun XS and Nguyen TA: Peptide hydrogelation and cell encapsulation for 3D culture of MCF-7 breast cancer cells. PloS one 8: e59482, 2013.

15. Loessner D, Stok KS, Lutolf MP, Hutmacher DW, Clements JA and Rizzi SC: Bioengineered 3D platform to explore cell-ECM interactions and drug resistance of epithelial ovarian cancer cells. Biomaterials 31: 8494-8506, 2010.

16. Goodman TT, Ng CP and Pun SH: 3-D tissue culture systems for the evaluation and optimization of nanoparticle-based drug carriers. Bioconjug Chem 19: 1951-1959, 2008.

17. Ma BB, Lui VW, Hui EP, Lau CP, Ho K, Ng MH, Cheng SH Tsao SW and Chan AT: The activity of mTOR inhibitor RAD001 (everolimus) in nasopharyngeal carcinoma and cisplatin-resistant cell lines. Invest New Drugs 28: 413-420, 2010.

18. Cai Y, Xia Q, Su Q, Luo R, Sun Y, Shi Y and Jiang W: mTOR inhibitor RAD001 (everolimus) induces apoptotic, not autophagic cell death, in human nasopharyngeal carcinoma cells. Int J Mol Med 31: 904-912, 2013.

19. Low SY, Tan BS, Choo HL, Tiong KH, Khoo AS and Leong CO: Suppression of BCL-2 synergizes cisplatin sensitivity in nasopharyngeal carcinoma cells. Cancer Lett 314: 166-175, 2012.
20. MacRae CA and Peterson RT: Zebrafish as tools for drug discovery. Nat Rev Drug Discov 14: 721-731, 2015.

21. de Jong M, Essers J and van Weerden WM: Imaging preclinical tumour models: Improving translational power. Nat Rev Cancer 14: 481-493, 2014.

22. Hoffman RM: Patient-derived orthotopic xenografts: Better mimic of metastasis than subcutaneous xenografts. Nat Rev Cancer 15: 451-452, 2015.

23. Sharpless NE and Depinho RA: The mighty mouse: Genetically engineered mouse models in cancer drug development. Nat Rev Drug Discov 5: 741-754, 2006.

24. Francia $G$ and Kerbel RS: Raising the bar for cancer therapy models. Nat Biotechnol 28: 561-562, 2010.

25. Tentler JJ, Tan AC, Weekes CD, Jimeno A, Leong S, Pitts TM, Arcaroli JJ, Messersmith WA and Eckhardt SG: Patient-derived tumour xenografts as models for oncology drug development. Nat Rev Clin Oncol 9: 338-350, 2012.

26. Liu T, Ding Y, Xie W, Li Z, Bai X, Li X, Fang W, Ren C, Wang S, Hoffman RM and Yao K: An imageable metastatic treatment model of nasopharyngeal carcinoma. Clin Cancer Res 13: 3960-3967, 2007.

27. Lum CT, Liu X, Sun RW, Li XP, Peng Y, He ML, Kung HF, Che CM and Lin MC: Gold (III) porphyrin 1a inhibited nasopharyngeal carcinoma metastasis in vivo and inhibited cell migration and invasion in vitro. Cancer Lett 294: 159-166, 2010.

28. Smith PA, Merritt D, Barr L and Thorley-Lawson DA: An orthotopic model of metastatic nasopharyngeal carcinoma and its application in elucidating a therapeutic target that inhibits metastasis. Genes cancer 2: 1023-1033, 2011.

29. Merlino G, Flaherty K, Acquavella N, Day CP, Aplin A, Holmen S, Topalian S, Van Dyke T and Herlyn M: Meeting report: The future of preclinical mouse models in melanoma treatment is now. Pigment Cell Melanoma Res 26: E8-E14, 2013.

30. Richmond A and Su Y: Mouse xenograft models vs GEM models for human cancer therapeutics. Dis Model Mech 1: 78-82, 2008.

31. Sutherland RM, Inch WR, McCredie JA and Kruuv J: A multi-component radiation survival curve using an in vitro tumour model. Int J Radiat Biol Relat Stud Phys Chem Med 18: 491-495, 1970

32. Mueller-Klieser W: Multicellular spheroids. A review on cellular aggregates in cancer research. J Cancer Res Clin Oncol 113: 101-122, 1987.

33. Evans CL: Three-dimensional in vitro cancer spheroid models for photodynamic therapy: Strengths and oppurtunities. Front Phys 3: 1-7, 2015.

34. Howes AL, Richardson RD, Finlay D and Vuori K: 3-Dimensional culture systems for anti-cancer compound profiling and high-throughput screening reveal increases in EGFR inhibitor-mediated cytotoxicity compared to monolayer culture systems. PloS one 9: e108283, 2014

35. Flach EH, Rebecca VW, Herlyn M, Smalley KS and Anderson AR: Fibroblasts contribute to melanoma tumor growth and drug resistance. Mol Pharm 8: 2039-2049, 2011.

36. Bruland O, Fodstad $\mathrm{O}$ and Pihl A: The use of multicellular spheroids in establishing human sarcoma cell lines in vitro. Int J Cancer 35: 793-798, 1985.

37. Mehta G, Hsiao AY, Ingram M, Luker GD and Takayama S: Opportunities and challenges for use of tumor spheroids as models to test drug delivery and efficacy. J Control Release 164: 192-204, 2012

38. Phung YT, Barbone D, Broaddus VC and Ho M: Rapid generation of in vitro multicellular spheroids for the study of monoclonal antibody therapy. J Cancer 2: 507-514, 2011.

39. Minchinton AI and Tannock IF: Drug penetration in solid tumours. Nat Rev Cancer 6: 583-592, 2006

40. Rohwer N and Cramer T: Hypoxia-mediated drug resistance: Novel insights on the functional interaction of HIFs and cell death pathways. Drug Resist Updat 14: 191-201, 2011.

41. Lucas KM, Mohana-Kumaran N, Lau D, Zhang XD, Hersey P, Huang DC, Weninger W, Haass NK and Allen JD: Modulation of NOXA and MCL-1 as a strategy for sensitizing melanoma cells to the BH3-mimetic ABT-737. Clin Cancer Res 18: 783-795, 2012.

42. Lo MC, Yip TC, Ngan KC, Cheng WW, Law CK, Chan PS, Chan KC, Wong CK, Wong RN, Lo KW, et al: Role of MIF/CXCL8/CXCR2 signaling in the growth of nasopharyngeal carcinoma tumor spheres. Cancer Lett 335: 81-92, 2013.

43. Lui VW, Lau CP, Ho K, et al: Anti-invasion, anti-proliferation and anoikis-sensitization activities of lapatinib in nasopharyngeal carcinoma cells. Invest New Drugs 29: 1241-1252, 2011. 
44. Lodish H, Berk A, Zipursky SL, Matsudaira P, Baltimore D and Darnell JE (eds): Molecular Cell Biology. 4th edition. W.H. Freeman and Company, New York, NY, 1999.

45. Seewaldt V: ECM stiffness paves the way for tumor cells. Nat Med 20: 332-333, 2014.

46. Sculier JP and Fry W: Malignant Tumours of the Lung: Evidence-based Management. Springer Berlin Heidelberg, 2012.

47. Gialeli C, Theocharis AD and Karamanos NK: Roles of matrix metalloproteinases in cancer progression and their pharmacological targeting. FEBS J 278: 16-27, 2011.

48. Li WW, Long GX, Liu DB, Mei Q, Wang JF, Hu GY, Jiang JZ, Sun W, Gan L and Hu GQ: Cyclooxygenase-2 inhibitor celecoxib suppresses invasion and migration of nasopharyngeal carcinoma cell lines through a decrease in matrix metalloproteinase- 2 and-9 activity. Pharmazie 69: 132-137, 2014.

49. Fennema E, Rivron N, Rouwkema J, van Blitterswijk C and de Boer J: Spheroid culture as a tool for creating 3D complex tissues Trends Biotechnol 31: 108-115, 2013.

50. Nederman T, Norling B, Glimelius B, Carlsson J and Brunk U: Demonstration of an extracellular matrix in multicellular tumor spheroids. Cancer Res 44: 3090-3097, 1984.

51. Lin RZ, Chou LF, Chien CC and Chang HY: Dynamic analysis of hepatoma spheroid formation: Roles of E-cadherin and betal-integrin. Cell Tissue Res 324: 411-422, 2006.

52. Givant-Horwitz V, Davidson B and Reich R: Laminin-induced signaling in tumor cells. Cancer Lett 223: 1-10, 2005.

53. Li L, Fukunaga-Kalabis M and Herlyn M: The three-dimensional human skin reconstruct model: A tool to study normal skin and melanoma progression. J Vis Exp (54) e2937, doi:10.3791/2937, 2011.

54. Smalley KS, Haass NK, Brafford PA, Lioni M, Flaherty KT and Herlyn M: Multiple signaling pathways must be targeted to overcome drug resistance in cell lines derived from melanoma metastases. Mol Cancer Ther 5: 1136-1144, 2006.

55. Smalley KS, Lioni M, Noma K, Haass NK and Herlyn M: In vitro three-dimensional tumor microenvironment models for anticancer drug discovery. Expert Opin Drug Discov 3: 1-10, 2008.

56. Breslin S and O'Driscoll L: Three-dimensional cell culture: The missing link in drug discovery. Drug Discov Today 18: 240-249, 2013.

57. Rimann M and Graf-Hausner U: Synthetic 3D multicellular systems for drug development. Curr Opin Biotechnol 23: 803-809, 2012.

58. Lee J, Cuddihy MJ and Kotov NA: Three-dimensional cell culture matrices: State of the art. Tissue Eng Part B Rev 14: 61-86, 2008.

59. Artym VV and Matsumoto K: Imaging cells in three-dimensional collagen matrix. Curr Protoc Cell Biol Chapter 10: Unit 10.18.1-20, 2010 .

60. Gu Z, Liu F, Tonkova EA, Lee SY, Tschumperlin DJ and Brenner MB: Soft matrix is a natural stimulator for cellular invasiveness. Mol Biol Cell 25: 457-469, 2014.

61. Zaman MH, Trapani LM, Sieminski AL, Mackellar D, Gong H, Kamm RD, Wells A, Lauffenburger DA and Matsudaira P: Migration of tumor cells in 3D matrices is governed by matrix stiffness along with cell-matrix adhesion and proteolysis. Proc Natl Acad Sci USA 103: 10889-10894, 2006

62. Vinci M, Gowan S, Boxall F, Patterson L, Zimmermann M, Court W, Lomas C, Mendiola M, Hardisson D and Eccles SA: Advances in establishment and analysis of three-dimensional tumor spheroid-based functional assays for target validation and drug evaluation. BMC Biol 10: 29, 2012.

63. Inoue $\mathrm{M}$, Endo $\mathrm{H}$, Ohue $\mathrm{M}$, et al: Cancer tissue-derived spheroid, CTOS, for evaluation of drug response from individual patient tumor samples [abstract 3832]. Cancer Research: 38322013.

64. Lee SH, Hong JH, Park HK, Park JS, Kim BK, Lee JY, Jeong JY Yoon GS, Inoue M, Choi GS and Lee IK: Colorectal cancer-derived tumor spheroids retain the characteristics of original tumors. Cancer Lett 367: 34-42, 2015.

65. Visvader JE and Lindeman GJ: Cancer stem cells in solid tumours: Accumulating evidence and unresolved questions. Nat Rev Cancer 8: 755-768, 2008.

66. Pastrana E, Silva-Vargas V and Doetsch F: Eyes wide open: A critical review of sphere-formation as an assay for stem cells. Cell Stem Cell 8: 486-498, 2011.

67. Fang CY, Wu CC, Hsu HY, Chuang HY, Huang SY, Tsai CH, Chang Y, Tsao GS, Chen CL and Chen JY: EGCG inhibits proliferation, invasiveness and tumor growth by up-regulation of adhesion molecules, suppression of gelatinases activity, and induction of apoptosis in nasopharyngeal carcinoma cells. Int J Mol Sci 16: 2530-2558, 2015
68. Katt ME, Placone AL, Wong AD, Xu ZS and Searson PC: In Vitro Tumor Models: Advantages, Disadvantages, Variables, and Selecting the Right Platform. Front Bioeng Biotechnol 4: 12, 2016.

69. Tibbitt MW and Anseth KS: Hydrogels as extracellular matrix mimics for 3D cell culture. Biotechnol Bioeng 103: 655-663, 2009.

70. Patil YB, Swaminathan SK, Sadhukha T, Ma L and Panyam J: The use of nanoparticle-mediated targeted gene silencing and drug delivery to overcome tumor drug resistance. Biomaterials 31: 358-365, 2010

71. Friedrich J, Seidel C, Ebner R and Kunz-Schughart LA: Spheroid-based drug screen: Considerations and practical approach. Nat Protoc 4: 309-324, 2009.

72. Shin CS, Kwak B, Han B and Park K: Development of an in vitro 3D tumor model to study therapeutic efficiency of an anticancer drug. Mol Pharm 10: 2167-2175, 2013.

73. Wong CH, Ma BB, Cheong HT, Hui CW, Hui EP and Chan AT: Preclinical evaluation of PI3K inhibitor BYL719 as a single agent and its synergism in combination with cisplatin or MEK inhibitor in nasopharyngeal carcinoma (NPC). Am J Cancer Res 5: 1496-1506, 2015.

74. Chan KC, Ting CM, Chan PS, Lo MC, Lo KW, Curry JE, Smyth T, Lee AW, Ng WT, Tsao GS, et al: A novel Hsp90 inhibitor AT13387 induces senescence in EBV-positive nasopharyngeal carcinoma cells and suppresses tumor formation. Mol Cancer 12: 128, 2013

75. Li YQ, He QM, Ren XY, Tang XR, Xu YF, Wen X, Yang XJ, Ma $J$ and Liu N: MiR-145 inhibits metastasis by targeting fascin actin-bundling protein 1 in nasopharyngeal carcinoma. PLoS One 10: e0122228, 2015.

76. Chan KC, Chan LS, Ip JC, Lo C, Yip TT, Ngan RK, Wong RN, Lo KW, Ng WT, Lee AW, et al: Therapeutic targeting of $\mathrm{CBP} / \beta$-catenin signaling reduces cancer stem-like population and synergistically suppresses growth of EBV-positive nasopharyngeal carcinoma cells with cisplatin. Sci Rep 5: 9979, 2015

77. Li YJ, Wu SL, Lu SM, Chen F, Guo Y, Gan SM, Shi YL, Liu S and Li SL: (-)-Epigallocatechin-3-gallate inhibits nasopharyngeal cancer stem cell self-renewal and migration and reverses the epithelial-mesenchymal transition via NF- $\kappa \mathrm{B}$ p 65 inactivation. Tumour Biol 36: 2747-2761, 2015.

78. Ou J, Luan W, Deng J, Sa R and Liang $\mathrm{H}: \alpha \mathrm{V}$ integrin induces multicellular radioresistance in human nasopharyngeal carcinoma via activating SAPK/JNK pathway. PloS One 7: e38737, 2012

79. Vicat JM, Ardila-Osorio H, Khabir A, Brezak MC, Viossat I, Kasprzyk P, Jlidi R, Opolon P, Ooka T and Prevost G, et al: Apoptosis and TRAF-1 cleavage in Epstein-Barr virus-positive nasopharyngeal carcinoma cells treated with doxorubicin combined with a farnesyl-transferase inhibitor. Biochem Pharmacol 65: 423-433, 2003.

80. Pioche-Durieu C, Keryer C, Souquére S, Bosq J, Faigle W, Loew D, Hirashima M, Nishi N, Middeldorp J and Busson P: In nasopharyngeal carcinoma cells, Epstein-Barr virus LMP1 interacts with galectin 9 in membrane raft elements resistant to simvastatin. J Virol 79: 13326-13337, 2005.

81. Lun SW, Cheung ST, Cheung PF, To KF, Woo JK, Choy KW, Chow C, Cheung CC, Chung GT, Cheng AS, et al: CD44+ cancer stem-like cells in EBV-associated nasopharyngeal carcinoma. PloS One 7: e52426, 2012.

82. Teramoto N, Maeda A, Kobayashi K, Hayashi K, Oka T, Takahashi K, Takada K, Klein G and Akagi T: Epstein-Barr virus infection to Epstein-Barr virus-negative nasopharyngeal carcinoma cell line TW03 enhances its tumorigenicity. Lab Invest 80: 303-312, 2000.

83. Zhou Y, Yang H and Fan W: Effects of combined (131) I-and CT-BAC 5 immunotherapy on NPC CNE-2 multicellular spheroids. Chinese Journal of Nuclear Medicine 1, 33-352001.

84. Wang GH, Liu CZ, Liang CS and Fan W: Experimental study of ${ }^{188} \mathrm{RE}$-BAC5 radioimmunotherapy on nasopharyngeal carcinoma. Nuclear Techniques 26: 375-379, 2003.

85. Cheung AK, Lung HL, Hung SC, et al: Functional analysis of a cell cycle-associated, tumor-suppressive gene, protein tyrosine phosphatase receptor type $\mathrm{G}$, in nasopharyngeal carcinoma. Cancer Res 68: 8137-8145, 2008.

86. Huang H, Luan W, Li J and Liang H: Role of integrin $\alpha \mathrm{V}$ in sensitivity to radiotherapy of human NPC. The Chinese-German Journal of Clinical Oncology 8: 86-89, 2009. 
87. Lo AK, Liu Y, Wang XH, Huang DP, Yuen PW, Wong YC and Tsao GS: Alterations of biologic properties and gene expression in nasopharyngeal epithelial cells by the Epstein-Barr virus-encoded latent membrane protein 1. Lab Invest 83: 697-709, 2003.

88. Luan W, Huang H and Liang H: Role of SAPK/JNK signaling pathway in multicellular resistance to radiotherapy for human nasopharyngeal carcinoma. Acta Academiae Medicinae Militaris Tertiae 21, pp 25, 2006

89. Xia H, Cheung WK, Sze J, Lu G, Jiang S, Yao H, Bian XW, Poon WS, Kung HF and Lin MC: miR-200a regulates epithelial-mesenchymal to stem-like transition via ZEB2 and beta-catenin signaling. J Biol Chem 285: 36995-37004, 2010.

90. Cheng Y, Cheung AK, Ko JM, Phoon YP, Chiu PM, Lo PH, Waterman ML and Lung ML: Physiological $\beta$-catenin signaling controls self-renewal networks and generation of stem-like cells from nasopharyngeal carcinoma. BMC Cell Biol 14: 44, 2013.

91. Chiu SH, Wu CC, Fang CY, Yu SL, Hsu HY, Chow YH and Chen JY: Epstein-Barr virus BALF3 mediates genomic instability and progressive malignancy in nasopharyngeal carcinoma. Oncotarget 5: 8583-8601, 2014.

92. Huang Z, Cheng Y, Chiu PM, Cheung FM, Nicholls JM, Kwong DL, Lee AW, Zabarovsky ER, Stanbridge EJ, Lung HL and Lung ML: Tumor suppressor Alpha B-crystallin (CRYAB) associates with the cadherin/catenin adherens junction and impairs NPC progression-associated properties. Oncogene 31: 3709-3720, 2012.

93. Lin $\mathrm{CH}$, Hung PH and Chen YJ: CD44 Is associated with the aggressive phenotype of nasopharyngeal carcinoma through redox regulation. Int J Mol Sci 14: 13266-13281, 2013.

94. Ma L, Zhang G, Miao XB, Deng XB, Wu Y, Liu Y, Jin ZR, Li XQ, Liu QZ, Sun DX, et al: Cancer stem-like cell properties are regulated by EGFR/AKT/ $\beta$-catenin signaling and preferentially inhibited by gefitinib in nasopharyngeal carcinoma. FEBS J 280 2027-2041, 2013.
95.Ng YK, Wong EY, Lau CP, Chan JP, Wong SC, Chan AS, Kwan MP, Tsao SW, Tsang CM, Lai PB, et al: K252a induces anoikis-sensitization with suppression of cellular migration in Epstein-Barr virus (EBV)-associated nasopharyngeal carcinoma cells. Inves New Drugs 30: 48-58, 2012.

96. Wang WJ, Wu SP, Liu JB, Shi YS, Huang X, Zhang QB and Yao KT: MYC regulation of CHK1 and CHK2 promotes radioresistance in a stem cell-like population of nasopharyngeal carcinoma cells. Cancer Res 73: 1219-1231, 2013.

97. Yang CH, Wang HL, Lin YS, Kumar KP, Lin HC, Chang CJ, Lu CC, Huang TT, Martel J, Ojcius DM, et al: Identification of CD24 as a cancer stem cell marker in human nasopharyngeal carcinoma. PloS One 9: e99412, 2014.

98.Huang H, Luan W, Li J and Liang H: Role of integrin $\alpha \mathrm{V}$ in sensitivity to radiotherapy of human NPC. The Chinese-German Journal of Clinical Oncology 8: 86-89, 2009.

99. Cheung ST, Huang DP, Hui AB, Lo KW, Ko CW, Tsang YS, Wong N, Whitney BM and Lee JC: Nasopharyngeal carcinoma cell line (C666-1) consistently harbouring Epstein-Barr virus. Int J Cancer 83: 121-126, 1999.

100. Fandi A and Cvitkovic E: Biology and treatment of nasopharyngeal cancer. Curr Opin Oncol 7: 255-263, 1995.

101. Hoe SL, Tan LP, Jamal J, Peh SC, Ng CC, Zhang WC, Ahmad M and Khoo AS: Evaluation of stem-like side population cells in a recurrent nasopharyngeal carcinoma cell line. Cancer Cell Int 14: 101, 2014.

102. Lin CH, Chao LK, Hung PH and Chen YJ: EGCG inhibits the growth and tumorigenicity of nasopharyngeal tumor-initiating cells through attenuation of STAT3 activation. Int J Clin Exp Pathol 7: 2372-2381, 2014

103. Wang J, Guo LP, Chen LZ, Zeng YX and Lu SH: Identification of cancer stem cell-like side population cells in human nasopharyngeal carcinoma cell line. Cancer Res 67: 3716-3724, 2007. 